\title{
Inventing International Students: Exploring Discourses in International Student Policy Talk, 1945-75
}

\author{
Dale M. McCartney \\ University of British Columbia
}

\begin{abstract}
After the Second World War, Canadian parliamentarians showed growing interest in international students coming to Canada. The students became the subject of policy talk, which was shaped by powerful discourses emerging from the larger historical context. From 1945 to 1969 , international students were seen as worthy recipients of Canadian aid, an idea that was premised on the belief that they were temporary visitors to Canada who would return to their home countries with both the skills they learned in Canadian schools and with an overall goodwill towards Canada, a valuable commodity in the Cold War context. But after the Sir George Williams University affair of 1969, parliamentarians' tone changed, and international student policy talk became suffused with discourses of fear and danger. In the years after 1969, international students were imagined as both politically and economically dangerous, an attitude that emerged as a reaction to student protest, but also reflected worries among some policymakers that Canada's changing immigration system, and its move away from primarily Europeans sources for immigrants, was a threat to the stability of Canadian culture.
\end{abstract}

RÉSUMÉ

Après la Seconde Guerre mondiale, les parlementaires canadiens ont montré un intérêt croissant pour la venue au pays d'étudiants internationaux. Ces derniers devinrent un sujet de discussions politiques qui donna lieu à des discours émouvants alimentés par un vaste contexte historique. De 1945 à 1969, les étudiants internationaux étaient vus comme des récipiendaires dignes de l'aide canadienne. Cette idée s'appuyait sur l'impression qu'ils étaient des résidents temporaires au Canada et qu'ils retourneraient dans leur pays non seulement avec les compétences acquises dans les établissements d'enseignement, mais qu'ils afficheraient aussi leur bienveillance envers le Canada, une valeur inestimable dans un contexte de Guerre froide. Cependant, après l'affaire de l'Université Sir George Williams, en 1969, le ton des parlementaires canadiens a changé. Les discussions politiques sur les étudiants internationaux furent teintées par des idées de peur et d'appréhension. Après 1969, on imagina les étudiants internationaux comme dangereux sur les plans politique et économique. Cette attitude fut une réaction aux protestations étudiantes, mais reflétait également les préoccupations de certains politiciens face aux changements du système d'immigration qui ne privilégiait plus les étudiants venus d'Europe, ce qui présentait une menace à la culture canadienne. 
In 1976, Progressive Conservative MP Gordon Fairweather rose in the house to critique the Liberal government's higher education policy, specifically regarding the funding of research. Fairweather felt obliged at the end of his address to turn his attention to international students and what he saw as disturbing developments in policy regarding their presence at Canadian universities. He started by reminding Prime Minister Pierre Trudeau that Trudeau himself "did not pay an extra fee because he was a Canadian student" when he studied at the Sorbonne or Harvard, something he shared with "hundreds of thousands of people around the world who have benefited from the generosity of respective national states." Thus, Fairweather felt, it would be unreasonable for Canada to introduce differential fees for international students. Indeed, he argued, it would hurt Canada in the long run: "Some of our great international universities which speak really to the world surely would never have gained such undoubted reputations if they had a sliding scale that affects people from all over the world." But Fairweather could tell which way policy was trending, and so he ended on a plaintive note, offering "a plea that the provinces in this country not take what I think is a retrograde step of having different requirements in money terms for people who come from outside Canada." 1

Fairweather's comments can be read as a eulogy ${ }^{2}$ for a different way of thinking about international students. This view was built on a philosophy of international aid and co-operation, rather than the current consumer model in which international students are customers in a global marketplace, recruited for what they offer to the Canadian economy - that is, money. ${ }^{3}$ In Fairweather's view, international students were travellers, like Trudeau, benefiting from generous countries and bringing the insights gleaned from their education back with them to their homelands. Fairweather was expressing a discourse of development through education, one that he saw as both to Canada's benefit and its duty.

Today Fairweather's view seems like a relic of a long gone age, but less than a decade earlier his view had been dominant among parliamentarians. Before 1970, the discourse addressing international students sounded much more like Fairweather's, although often more neo-colonial than the way he formulated it in 1976. After 1970, though, Fairweather was out of step with the developing course of policy talk regarding international students, who had come to be discussed as potentially dangerous interlopers in Canada. It is this transition - from targeting international students to be recipients of Canada's self-interested largesse to fearing them as a threat to Canada's economy and social structure - that this article will explain.

The evidence is drawn from public debate in the House of Commons about international students, as documented in Hansard. These debates were chosen not because they were the most important location for policy-making or even because parliamentarians are able to coherently speak for the state they govern. As Leo Panitch points out, the state and its operation are much broader than the government alone, and election to government does not necessarily grant control of all aspects of the state. ${ }^{4}$ American historians of education David Tyack and Larry Cuban make a similar point in reference to education specifically when they point out that the "basic grammar of schooling ... has remained remarkably stable over the decades," despite 
generations of reformers being elected at all levels of government. ${ }^{5}$ That is to say, the fundamental elements of the delivery of education - for example, the shape of classrooms or the division of material into subjects - have remained consistent for decades. ${ }^{6}$ Making substantial policy change is not a simple thing, and new parties in power do not necessarily put their unique stamp on policy.

Yet the public debates of parliamentarians are still important records that have been underutilized by historians of education. Parliamentary discussions indicate the contours of debate at a given moment. Thus they are useful for two reasons when undertaking historical policy analysis: on the one hand, they show the range of choices that were considered as policy options, allowing us to reconstruct the swirling cycles of policy debate. On the other, they also reveal the embedded discourses operating within public discussion of policy, discourses that often originate outside of Parliament but still come to define that debate. Often what is most instructive about these debates is not necessarily what gets argued - but what does not. There are assumptions contained within every political position that often go unexamined and unquestioned. When a broad array of politicians all share assumptions, one can see the power of a discourse. This article is not suggesting that these discussions always defined actual policies (although in some cases they did), but instead argues that the debates reveal something important about the perceptions of international students among parliamentarians.

This article treats parliamentary debates as examples of what Tyack and Cuban call "policy talk," and links it to Stephen Ball's conception of policy as both text and discourse. ${ }^{8}$ Tyack and Cuban describe policy talk as "diagnoses of problems and advocacy of solutions." Thus policy talk is not simply a conversation about educational policy; instead it is an opportunity for policy-makers to try to lay the groundwork for future policy. In this way, studying policy talk requires an attempt to understand the agency of politicians, while recognizing that they operate within certain constraints, both political — the pressure to be re-elected, and governmental — the need to govern society and to govern it within certain parameters. As Tyack and Cuban explain, policy talk does not always translate to policy creation or implementation, but it defines the range of options available and can prefigure the shape of actually enacted policy. ${ }^{10}$

Because of these constraints - political and governmental pressures - policy talk is never generated in a vacuum. Instead, it is freighted with meaning outside of its parliamentary context - it is loaded with discourses. By discourse, I mean the (sometimes unspoken) assumptions, values, and notions that underpin and organize policy talk. Parliamentarians and policy-makers more broadly operate within discursive fields, but they also contest them. Therefore, attending to policy talk is an important historical opportunity that reveals these discourses and allows an analysis of how they shift and change. Policy talk describes parliamentary debate, the swirling diagnoses of educational problems, and operates at the level of talk, because its relationship to actual policy-making and policy implementation is not always clear. ${ }^{11}$ Discourses are present within and surrounding these policy conversations, defining their shape and content, but these discourses are also being formed and contested within this policy debate. ${ }^{12}$ 
International students as a group are the subjects/objects of a sizeable amount of policy and policy talk at all levels of the Canadian government, as well as within institutions themselves. ${ }^{13}$ This article is an attempt trace a few prominent discourses operating in discussions of policy in the post-Second World War era, to begin situating the emergence of the discursive construction of "international students" between 1945 and 1975 .

\section{5-1969: International Students as Welcome Sojourners}

In the first twenty-five years after the Second World War, discussions about students who were not Canadian citizens ${ }^{14}$ were firmly located within debates about Canada's changing place in the world. This policy talk was shaped by the discourses emerging out of Canada's foreign affairs concerns: Canada's role in the Cold War and its emergence as an international economic power. Even at this early stage, policy talk, while ostensibly about education, was never only about education, or only about students. Parliamentarians were always framing their discussions of international students within a larger set of policy goals, many of which had nothing to do with education - or the students themselves.

It becomes obvious while reading the debates about these students that took place in the House of Commons that the dominant discourse operating within policy talk at the time was that international students were development targets, that is, they were worthy recipients of Canadian development funds. But this was not simply an act of charity. While the "main objective" of such aid is to promote "economic and social development" this objective had to compete with a variety of others, including, but not limited to, "strategic, political, commercial, and non-developmental humanitarian concerns" that might be in concert, but were sometimes in conflict, with the goal of development. ${ }^{15}$

Parliamentarians' discussions of international students were also bound up in Canada's notion of itself. Robert Bothwell suggests that, in the period examined here, Canada perceived itself to be a junior partner in a North Atlantic "triangle" that also included Britain and the United States. ${ }^{16}$ Within this triangle, Canada imagined itself to be a "moral superpower," in a unique position to serve as a mediator with the Third World. ${ }^{17}$ This was often part of Canada's self-perception as a "middle power." 18 Bothwell suggests that the idea of middle power status might have been more wishful thinking than fact, in that Canada was rarely listened to on the international stage. ${ }^{19}$ Nonetheless, according to diplomat Arthur Andrew, the idea of Canada as a middle power became "not a separate agenda item but a philosophical outlook that was built into the government's position on whatever happened to be at hand": that is, a discourse working among foreign affairs policy-makers. ${ }^{20}$ It had become a core value shaping policy talk by $1955 .{ }^{21}$

On the face of it, aid programs fit well within a self-conception as a moral superpower, but in the first decade after the Second World War Canada showed limited interest in overseas development programs, instead focusing on "diplomacy and security." 22 It was only when the link between the Commonwealth and international 
security became clear that Canada began to emphasize foreign aid as part of its foreign policy, especially multilateral aid. ${ }^{23}$ Thus, throughout this period, Canada's aid policy was shaped by the larger Cold War goals of the government. ${ }^{24}$ Canada targeted former British colonies as aid recipients, starting in Asia with the Colombo plan in 1950, and then in the Caribbean and Africa after $1958 .{ }^{25}$ International education, including international students, was a small but important part of these aid programs. $^{26}$

Some historians have looked at this period very favourably: Roopa Desai Trilokekar has characterized this era as one of "humane internationalism" on the part of Canada. ${ }^{27}$ She argues that aid programs, including programs that gave development money to international education, "fit well with Canada's [international] heritage as a non-colonial middle power." ${ }^{28}$ Similarly, Costas Melakopides has argued that "Canada has been an enlightened and distinguished member of the international community" since the Second World War, pursuing a "pragmatic idealism" that reflects the "Canadian internationalism" that was at the heart of Canadian mainstream political culture from 1945 to $1995 .^{29}$

But the aid programs were not entirely altruistic: as political scientist Keith Spicer put it at the time, reflecting the opinion of many politicians, Canada had "a right to expect some worthwhile results" from this transfer of wealth. ${ }^{30}$ Indeed, Canada's goal was always "political and commercial rather than humanitarian." ${ }^{1}$ Aid monies had been spent usefully if they contributed to "development" in the form of infrastructure or if they created political goodwill, especially anti-communist attitudes, among the recipients. ${ }^{32}$ Aid was understood by policy-makers to be "a force in what is often termed the 'war for men's minds,"” an aspect of the battle to stop the spread of communism. ${ }^{33}$

The same discourses are clearly visible in discussions of international students. According to parliamentarians, international students who might learn the skills to help their home countries "develop" were the kind of foreign students Canada desired. Moreover, students visiting Canada were expected to learn to dislike communism and value liberal capitalism. While politicians may have overestimated "the gratitude that aid might generate and how long such goodwill might last," Canadian politicians before 1969 believed that the value of welcoming international students to Canada was to be found in the development of both skills and warm feelings towards Canada and the West in general. ${ }^{34}$

Thus, close examination of the parliamentary debate about international students illuminates deeply neo-colonial discourses suffusing policy talk. Education has had a long historical role in the work of empires, and much of that history echoes in these discussions. As John Willinsky has shown, educational systems constructed in the classical imperial era for colonized students were not only imperial in content but in form; similarly, Canadian parliamentarians regarded international students as targets not only for the valuable "developmental" content of Canadian pedagogy, but also for the re-socialization that they believed would result from exposure to the perceived superiority of Canadian society. ${ }^{35}$ Policy-makers often spoke in ways that exhibited a neo-colonial paternalism. ${ }^{36}$ 
A clear explanation of the idea of neo-colonialism can be found in the work of Kwame Nkrumah, the first prime minister of an independent Ghana and one of the leading figures in both pan-Africanism and the international non-aligned movement of countries trying to resist the influence of both the USA and USSR in the Cold War. ${ }^{37}$ Nkrumah, who saw neo-colonialism as one of the great threats facing African nations attempting to free themselves from colonial empires, described a system in which states appeared independent but had an economic system whose form was dictated by neo-imperial powers according to a neo-colonial model. He insisted that this was not simply a matter of economic policy, but that it operated in the "political, religious, ideological and cultural spheres" as well. ${ }^{38}$ Ania Loomba points out that the "economic (and social) relations of dependency" that underpin neo-colonialism have their roots in the long history of direct colonialism. ${ }^{39}$ But neo-colonialism emerged after the Second World War when, according to Kuan-Hsing Chen, colonial empires did not collapse: "rather, the direct territorial mode of control [gave] way to direct or indirect political and economic maneuvering." ${ }^{40}$ Because parliamentarians seemed to believe that education in Canada would give international students the skills required to "develop" their home countries in Canada's image, and, more importantly, would ensure that they desired to restructure their home countries in this fashion, their attitudes are representative of the ideological and cultural elements of neo-colonialism. Their characterization of students was paternalistic in that MPs saw international students as somewhat child-like outsiders, coming to Canada to gain the skills necessary to "develop." International students were not considered potential Canadians within these debates. Instead they were regarded as sojourners by nature, present in Canada due to the benevolence of a generous government, with the assumption that they would return to their home countries, taking with them the intellectual and cultural rewards of their time in Canada.

Ultimately, these policy discussions reveal more about what politicians assumed about these students than about the students themselves. There was little actual data offered about these students in Parliament, and when it was offered, it was almost entirely quantitative and gave very little insight into the character, interests, or educational goals of the students themselves. ${ }^{41}$ Students' voices were entirely absent. As we shall see, even when their actions drew the government's attention, there was almost no interest in the substance of their demands, only to the form of their protests. Yet parliamentarians regularly spoke authoritatively of these students, of their desires, of their place in the world, and of the wonderful experiences Canada was providing them. These ideas were only occasionally explicit in policy talk, but they ran as a current throughout discussions, by all political parties, of foreign students before 1969 .

The basic contours of the ideas that were shaping policy talk are visible as early as 1953. In a debate about how to spend Canada's foreign aid funds, Cooperative Commonwealth Federation (CCF) MP Stanley Knowles insisted that "nothing is more basic to the future peace of the world than that we take far more seriously than we have done to date this question of our responsibility to try to assist the underdeveloped portions of the world." 42 
To this end, Knowles insisted that more money needed to be spent on bringing students from "underdeveloped" countries to Canada. As he lamented, "we have spent out of Canadian funds 190 times as much on the training of foreign military personnel under NATO [North Atlantic Treaty Organization] as we have spent on the training of foreign students" - proof in his opinion that Canada had "not yet faced up to the challenge of this other task of helping to train people from these underdeveloped countries so they might be able to go back and do a job in helping to raise the living standards of their own countries in a way that could be done by improving their methods of agricultural production and by expediting their industrialization." ${ }^{43}$

This view was coherent enough that almost a decade later New Democratic Party (NDP) MP Walter Pitman echoed his colleague's point, telling Parliament that investing in research and development for underdeveloped countries - including bringing foreign students to Canada and "thus enabling them to take this knowledge back to their country" - was important because Canada stood "at a fork in the road. One road leads to our complete annihilation, while the other leads to the end of poverty, sickness and disease throughout the world." ${ }^{44}$ For the CCF/NDP, the stakes of international education were very high - the fate of the world rested upon it. In their view, international students were targets for development, vessels to be filled with Canadian technical skills and returned to their home countries to do good.

It was not only Canada's social democratic party that proposed such ideas. A few months after Pitman's statement that the world faced annihilation unless Canada showed a greater dedication to development, Frank McGee, an Ontario MP from the governing Progressive Conservatives who served on the standing committee for external affairs, echoed the NDP's points. Arguing that more money had to be dedicated to funding international students interested in studying "engineering, tropical agriculture and other faculties which lend themselves to humanitarian aid to the underdeveloped countries," McGee insisted that the government also had to better co-ordinate its departments, to "assist in the training of individuals in logical and effective skills in order to help in the development of these countries." 45

For McGee, as for the CCF/NDP MPs, the issue was not just practical development. It was also about developing a different sort of world. While the left-wing MPs emphasized the need for development to ensure peace through good relations in the future, McGee argued that inviting international students to Canada would have the benefit of educating them in democracy, thereby ensuring a more stable and peaceful world. Describing this task as important because Canada was "faced with the compelling challenge of communism," and suggesting "the communists act, and we react, having lost our initiative," McGee urged his colleagues, and Canadians more broadly, to better support the inculcation of what he called democratic values among international students.

It seems to me in this area a unique opportunity is provided for Canadians particularly around university cities. As I have indicated, there are approximately five thousand young men and women coming to Canada from Africa, from Asia, and the West Indies and other similar areas. It is the flavor of democracy 
which they acquire during their experience here which will be of greater value to Canada and certainly to the cause of democracy generally than perhaps many of the millions of dollars spent in other ways ...

These young men and women will return to the countries of their origin and will become beyond a shadow of a doubt the leaders and members of the corps surrounding the leaders which will guide their respective nations to their ultimate destinies in the coming generation. ${ }^{46}$

In case his audience was not entirely clear on the stakes, a few moments later McGee reminded Parliament of the importance of this effort: "By continuing the good work in this direction, already to no little extent commenced, we can provide the bulwark of education in democracy and counteract the propaganda on the part of the communists." ${ }^{47}$ McGee, like his colleagues across the aisle, saw international students as more than just learners - they were objects in Canada's foreign policy initiatives. An important discourse is clearly visible here: students who could potentially benefit from Canadian education that would provide them with the skills that parliamentarians assumed were needed in less wealthy countries were worthy to receive money from the government to gain access to that education. In turn, Canada would benefit from the goodwill such charity would create, and from the inculcation of Canadian democratic values in these visiting students. This discourse excludes international students from being recognized as potential immigrants. It also imagines all international students to originate from less-developed countries, or perhaps more accurately from Third World countries, which implied both underdeveloped and politically unaligned in the parlance of the Cold War. ${ }^{48}$ In fact, of the 7,251 international students studying in Canada in the 1960-61 school year, 1,242 were from (mostly western) Europe and 2,362 were from the US. That is to say that about half of the foreign students in Canada were actually from the First World. But there was no sign of this in the policy talk among parliamentarians, because the discourse shaping the debate meant that international students were always assumed to be aid targets. ${ }^{49}$

International students as aid targets remained a key theme in debates throughout the 1960s. Some parliamentarians were even more blunt about the historical role of education as colonial development. Robert Thompson, the leader of the Social Credit party, told Parliament that "colonialism had its purpose. It brought law and order, it trained primitive peoples, it brought education and the chance of a higher way of life to the areas that it administered." But while the need for these "benefits" remained, they could "no longer be imposed by force. They must be given in good will." ${ }^{0}$ Thus he pushed for greater funding to bring more international students from Africa to Canada - to continue the historic mission of colonialism, but now with an eye towards developing world peace and preventing the spread of communism. ${ }^{51}$

This discourse remained coherent and meaningful within policy talk until at least 1969, although it was still in circulation as late as the 1980s. ${ }^{52}$ In 1964 , Arnold Webster, an NDP MP from British Columbia, complimented the federal 
government on its scholarship program for students from developing countries within the Commonwealth, once again arguing that such supports would ensure peace and goodwill in the future. ${ }^{53} \mathrm{He}$ was echoed almost word for word the next year by his NDP colleague Reid Scott. ${ }^{54}$ As late as 1969, Liberal Secretary of State for External Affairs Mitchell Sharp was still discussing the notion of foreign students as recipients of aid without inviting controversy. ${ }^{55}$

Throughout this policy talk, the idea of international students as recipients of aid was premised on certain assumptions - one was that these students came from countries that were both less wealthy than Canada and were politically relevant in the geo-political landscape of the Cold War. Another was that they were not intending to immigrate to Canada, but were instead planning to return to their home countries, taking the skills and values they had developed in Canada with them. A third was that those values were both superior to the students' own and were worth spreading for strategic reasons. Finally, each of these was based on the assumption that Canada was both wealthy and munificent enough to be able to afford these programs. While there was broad support among politicians for bringing international students to Canada, they were only welcome in specific circumstances that served Canada's international agenda during the Cold War. ${ }^{56}$

\section{7-1969: The Sir George Williams University Affair and Shifting Policy Talk}

In the long run, the overwhelming threat to Canada will not come from foreign investments or foreign ideologies, or even — with good fortune — foreign nuclear weapons. It will come instead from the two-thirds of the people of the world who are steadily falling farther and farther behind in their search for a decent standard of living. — Pierre Trudeau, $1968^{57}$

As early as 1967, parliamentarians began to raise questions about whether attracting international students to Canada still served the country's Cold War interests. With those questions came challenges to the prevailing discourses about international students. Asking these questions was Ralliement créditiste MP Raymond Langlois. Langlois, himself an educator, inquired of the government about the costs of the portion of the "external aid" program that was being spent on international students. ${ }^{58}$ The next day he used the government's response to argue against funding for foreign students - the first MP to do so in the post-war period.

Langlois's critique of the funding signaled the beginning of an important shift in attitudes towards international students in Canada. Langlois started by reminding Parliament of the amount of funding received by students who were studying in Canada (Langlois claimed it was \$5,467.29/year on average) ${ }^{59}$ and then discussed the privilege this represented for these students: "we finance students to come to Canada to study, students who do not have the same problems Canadian students have. As far as finances are concerned, they are treated better than Canadian students." ${ }^{60}$ Langlois was just getting started: 
These [the international students] are students who have been changing [buying new] cars every year. They are about the brightest students from these underdeveloped countries. Some of them do not have to work so hard and some attend a minimum of courses. Their financial problems are minimal compared with some Canadian students who have to slave their way through university. ${ }^{61}$

It is clear from Langlois's comments that some MPs were critical of the cost of the aid programs for international students. He made this point again a few days later, chiding the government for telling Canadians to tighten their belts in a time of high inflation, even as they continued to fund foreign aid programs. ${ }^{62}$ But his critique was about more than just money. It was also an attack on the fundamental purpose of these programs.

Explaining that he believed that funding foreign students missed the point of external aid entirely, Langlois complained that students were given a Canadian education "so they can return to their homeland to render their country a service. The problem is, Mr. Speaker, they do not go back home." ${ }^{3}$ Langlois was referring to a United Nations (UN) study that allegedly demonstrated that there were 85,000 Indian medical students from schools all over the world who had not returned to their home country after finishing their training. Langlois explained that in this case funding international students was not only unfair to Canadian students but also was bad for developing countries. "We are doing [underdeveloped countries] a disservice," he said, by "taking their best students away from them." ${ }^{64}$ Langlois offered no Canadian evidence to support his contention that international students were staying after finishing their degrees, yet nonetheless insisted that a change in behaviour had occurred, one that undermined the long-held goals of the government's international student policies.

Two important assumptions about international students were being challenged by Langlois. The first was that international students needed or deserved help more than Canadians did. "Why supply foreigners with a remedy and let our own people suffer?" Langlois asked, a quick summation of the changing attitude towards international aid embedded within his comments. ${ }^{65}$ The second discursive shift within Langlois's policy talk is the complaint that international students were not returning home. This was a change from the dominant assumption that foreign students were sojourners who would take Canadian values home with them when they left after receiving their degrees. In laying out his concerns that international students were no longer temporary residents, Langlois was not simply responding to the pressures on the government's budget created by international students — instead, his speeches should be seen within the broader context of changing immigration policy.

From 1952 to 1967, as Robert Harney has shown, immigration policy "was intended to secure the type of immigrants that Canada's political leadership had sought shortly after World War II," ${ }^{66}$ that is, "American, British, French, Belgian, Dutch, Swiss, German, Scandinavian, and Icelandic settlers." ${ }^{67}$ In that same period, discussions of international students revolved around the assumption that such students 
were, virtually by definition, not from those countries. Thus there was no intersection between immigrants and international students - they were completely discrete categories. But by the late 1960s, this was clearly coming to an end. Not only because, as Langlois had suggested, international students were not performing the role they had been appointed, but also because Canada's immigration policy was changing to satisfy the economy's relentless demand for immigrants.

As Europe's economy recovered from the damage caused by the war, there were fewer European immigrants moving to Canada. ${ }^{68}$ The Liberal government of the 1960s responded by seeking what Reg Whitaker calls "managerial solutions to immigration problems." ${ }^{69}$ They moved responsibility for immigration away from the Ministry of Citizenship and Immigration, and placed it within the purview of the Department of Manpower and Immigration. A small change in semantics actually signaled a significant shift in policy. As Harney explains, "immigration policy has always reflected a dialectic between the desired population increase and the impact of immigration on Canadian ways or on the racial and ethnocultural composition of the country." ${ }^{\prime \prime}$ In the 1960 s, with the immigrant groups who were preferred for their ethnocultural contribution becoming increasingly scarce, the pressure to increase the population to keep up with economic demand drove policy changes - thus the move of immigration into the ministry responsible for work. "Immigration was now seen simply as an aspect of the employment market and the primary variable in regard to immigration was the Canadian economy's absorptive capacity," ${ }^{71}$ which meant a shift away from recruiting immigrants who would easily find a cultural home in Canada, towards welcoming populations with very different cultural backgrounds who could contribute economically. There were discourses about immigration influencing policy talk that could be used to both justify and resist this shift. Harney describes this period of change as "the transformation of polyethnicity from a social consequence of recent immigration to its assertion as a permanent feature of the Canadian political landscape," eventually in the form of multiculturalism.

Franca Iacovetta argues that as the population of Canada diversified there was a tendency for "gatekeepers" to emerge who set themselves the task of transforming "immigrants into productive, democratic citizens," in the process pushing them to "conform to 'Canadian ways' - which usually reflected Anglo-Canadian middleclass ideals." 72 This gatekeeping was motivated by the cultural concerns that Harney traces throughout Canadian history, but it was also a reflection of Cold War fears. Immigrants were seen as potentially dangerous, and the federal government and its security apparatus were "on high alert and poised to do battle against the variously defined threats to the nation's political as well as social and moral order." ${ }^{73}$

Of course, international students were not exempt from these contextual shifts - indeed, discussion of them was implicated at their core. That is because they came to represent the perceived risks of this new immigration policy. The confidence that parliamentarians had had in the civilizing mission of programs that brought international students to Canada was eroded by the claim that those students were no longer going home after graduation. Instead of sojourners, these students were now immigrants, and as such were part of changing immigration patterns and policy. 
Europe had been the source of 65 per cent of the immigrants to Canada in 1968, but by 1984 provided only 24 per cent of immigrants, while Asia was the source of 50 per cent of immigrants to Canada in 1984, after accounting for only 12 per cent in $1968 .{ }^{74}$ As part of this important change in Canadian society, policy talk about international students began to reveal a discourse that imagined them not as happy recipients of aid money, but instead as threats to Canadian stability and order.

Specifically, policy talk about international students after 1969 (until at least 1975) was characterized by discourses of danger. This danger was rarely an academic concern, but instead took two forms. One, visible in Langlois's questions, was an economic uneasiness, a fear that international students were going to take funding that might have gone to Canadians, or worse yet jobs that could have gone to Canadians.

But perhaps even more powerful was a fear that foreign students might be a bad influence on Canada and Canadians, and that they represented a threat to otherwise orderly higher education institutions. This was certainly the result of deepening Cold War tensions. But it also reflects the dialectic expressed by Harney between economic necessity and cultural preference, the tension that he suggests has defined each era of Canadian immigration policy. ${ }^{75}$ Harney argues that Canada, more than most countries, has conflated "maintaining a viable political state and achieving a successful (i.e., integrative) nationalism as an ideology and identity for those who live within that state." "T6 Therefore defining "Canadian" values and who was and was not Canadian had existential importance to some policy-makers. Discussions of international students after 1969 were shaped by these fears.

Placing the emerging tension regarding international students within this context, one can see that international student discourses changed as a result of larger changes in the concept of Canada as a nation, which was then reflected in the policy talk about those students. In the 1960s, "the British definition of Canada" that had been widely shared in English Canada after the Second World War was discarded, and "the new definitions of Canadian identity that emerged remained amorphous" until late in the decade. ${ }^{77}$ The emergence at the end of the decade of what would be called multiculturalism and its efforts to organize the state apparatus occasioned resistance in the form of growing concern about who or what ideas were being recognized as "Canadian"; some of that resistance focused on a category that was, by definition, not Canadian: international students. ${ }^{78}$ Similarly, convincing everyday people to be ideologically invested in this new element of the national project required clear delineation of who would be excluded - any national identity has to be constituted not only by those it includes but also by whom it excludes. ${ }^{79}$ The emergence in policy talk in the late 1960s of a discourse of international students as dangerous, particularly as dangerous potential immigrants, is not coincidental. Instead, it was a small but important part of creating a new meaning for the idea of "Canadian."

The key event in the trajectory of international student discourses from deserving recipients of charity to potentially dangerous foreigners threatening the Canadian way of life happened at Montreal's Sir George Williams University in 1969. The affair serves as an important turning point, one in which a crisis or a political opportunity focused policy talk and offered clear insight into the shifting discourses 
contained within that policy debate. In this case, the tensions between efforts by the government to increase immigration butted up against the cultural and political dangers seen to be present in the diversifying population, represented in this case by international students. Importantly, it is not likely that the Sir George Williams University affair itself caused a shift in attitudes towards international students. As has been argued above, the cause of this change was more complex. Moreover, in the late 1960s there was an international student uprising that surely shaped parliamentarians' response. ${ }^{80} \mathrm{MPs}$ evinced an intense focus on the role of international students in the event, consistently blaming outside agitators and rarely, if ever, discussing the responsibility of Canadian students. This virtual obsession with the role of international students suggests that their reaction was not simply a concern about student protest generally, but that their response was shaped by other elements. As a result, the discussion of the affair offers considerable insight into how dramatically attitudes had changed and become the discourses underpinning policy talk by 1969 .

In the spring of 1968, students at Sir George Williams University in Montreal (now a part of Concordia University) complained to the administration that a specific biology lecturer was marking in a discriminatory fashion, assigning lower grades to black and Asian students. Although the administration met with the complainants, the students did not feel that the school was taking the complaints seriously. Inspired by a rising tide of Black Power and anti-Vietnam War activism in Montreal at the time, two hundred students occupied the computer room of the campus, which was on the ninth floor of the building, holding it from January 29 to February 11, 1969, and eventually throwing tens of thousands of punch cards for the computers out of the windows of the lab, littering the street below. On February 11, the city police attacked the lab to evict the protestors. In the ensuing violence, the computer lab caught fire, and in one of the enduring images of the event, a hostile crowd on the street below - gathered to counter the student protest — chanted racist slogans as smoke billowed from the windows. Ultimately more than a million dollars of damage was done to the computers and ninety-seven students were arrested. ${ }^{81}$

Members of Parliament on both sides of the aisle and from across Canada reacted quickly, and strongly. Wally Nesbitt, a Conservative MP from Ontario, brought it up in Parliament on January 30, the second day of the occupation. He pointedly asked "whether the government is giving consideration to the curtailment of grants to foreign students attending Canadian universities under government auspices who engage in activities involving breaches of the peace, bloodshed and other acts of disorder?" 82 Nesbitt was clearly trying to push the government into reacting to what was an evolving situation, and that was a continuing theme of the reaction to the affair: opposition parties attempting to trip up the governing Liberals. Also clear was that international students would be the focus of blame for the events in Montreal.

Much of the parliamentary discussion of the incident was occurring within a context in which opposition MPs were trying to embarrass Pierre Trudeau's government on the issue of immigration. ${ }^{83}$ But there was more than just point-scoring at stake in the debate about the affair. Seen in the context of the larger discussion of international student policy, the reaction by opposition parties was more than just 
scapegoating or opportunism; it revealed a real mistrust of international students, one that appeared to be both racialized and linked to the changing social location of international students from visitors to potential immigrants.

Parliamentarian attitudes towards international students in the wake of the Sir George Williams affair demonstrated a great concern about the political and social influence of international students on their Canadian classmates. In part this was a reflection of the concern expressed by Langlois, that international students - by which, as we have seen, parliamentarians meant students from the Third World - were increasingly settling in Canada after their studies. In this case, international students were no longer aid recipients but instead were future residents of Canada. As Himani Bannerji argues, Canada's "imagined community" had historically been concomitant with "whiteness"; international students (as part of a larger shift in immigration) were seen as a threat to the coherence of this identity. ${ }^{84}$

The Sir George Williams affair was "the immediate spark that set off a Black renaissance" in Montreal, a renaissance that was informed by international anti-colonialism and Black Power ideas. ${ }^{85}$ These ideas, which grew in popularity in Montreal after a stirring speech was given by Stokely Carmichael at McGill in 1968, had originally arrived with anti-colonial activists from the Caribbean. Among the most prominent figures in crafting this anti-colonial critique were Rosie Douglas, an international graduate student from Dominica, and Alfie Roberts, a native of St. Vincent and the Grenadines. Both were arrested during the Sir George Williams affair. ${ }^{86}$ This is not to say that the Sir George Williams affair was a foreign issue. As David Austin argues, the protests were clearly "an autochthonous response to racial discrimination in Montreal and Canada in general, and evidence of the unwillingness of Black Canadians to suffer it." ${ }^{87}$ But the participants in the affair "conceived of their efforts as an attempt to bring democracy to the community, the country, and the world" 88 — they were part of an international struggle against neo-imperialism, as well as mounting a challenge to the racist basis of Canadian identity in the $1960 \mathrm{~s} .{ }^{89}$

Therefore, for parliamentarians the Sir George Williams affair was not simply an example of student unrest, but was instead part of an international trend that challenged the earlier basis upon which international student policy talk had been premised. That earlier discourse of Canada as a generous benefactor and international students from the Caribbean as the recipients of Canada's largesse was deeply rooted in international student policy talk; the Sir George Williams affair threatened to explode such notions. Thus many parliamentarians reacted angrily, and international students were seen, not as important allies to be recruited in the Cold War, but instead as ungrateful troublemakers who threatened the stability of Canadian universities.

After the opening salvo on January 30, the Progressive Conservatives pressed their advantage, questioning any minister they could about the events in Montreal - the secretary of state for External Affairs, the solicitor general, the minister of Transport, the minister of Finance, the minister of Manpower and Immigration, and the minister of Justice, and, of course, the prime minister. ${ }^{90}$ Their demands focused on the government launching a full inquiry. 
Perhaps because the government refused such an inquiry, opposition MPs offered their own theories about the root causes. All of them pointed out the prominence of foreign students (one Liberal MP reported that forty-five of the ninety-seven arrested were non-Canadians), ${ }^{11}$ but many went much further. Ralliement créditiste MP Gilbert Rondeau demanded to know whether the government was going to open an inquiry to determine the role of "Mao followers" in the events at Sir George Williams University. ${ }^{92}$ Similarly, his fellow créditiste, Henry Latulippe, asked whether or not "it would be advisable to change or to put off the approaches made to China, in order to ascertain whether that communist country was involved in those acts of sabotage?"93 Others suggested that this was because the government permitted "a large percentage of foreigners to come into Canada," some of whom then went on to "cause trouble in our universities." 94 Several MPs suggested forceful solutions: a Liberal recommended deportation for disorderly international students; ${ }^{95}$ others recommended pulling loans to rebellious students, foreign or Canadian, ${ }^{96}$ or cutting funding for international students who participated. ${ }^{97}$ There was also great interest in the exact legal standing of the students involved, and discussion of whether their visas could be revoked. ${ }^{98}$ It was clear by 1969 that whatever energy there had been to teach international students "the flavour of democracy" had been eclipsed by new concerns.

Even as parliamentarians were debating what to do about the occupation, it was already being put to other purposes. On February 13 (two days after the occupation had ended), in a debate about abortion, créditiste Henry Latulippe recommended that instead of making abortion more available, "some way should be found to change the conditions making pregnancy undesirable." Latulippe insisted that "if the mother felt able to provide an education and a decent living to her child" then she would eschew abortion. In that case, Canada "would not have to bring over millions of immigrants. We could go on building up our society, which would develop and also be healthier. We might never witness again what happened at Sir George Williams University." 99 Within two days of the end of the stand-off, a new discourse had come into play and was influencing policy talk widely.

One consequence, then, of the Sir George Williams affair was that MPs who feared expanding immigration had found an easy touchstone for their complaints. The affair captured many of the fears and tensions then in play in discussions of immigrants, including international students. Almost none of the parliamentary discussion addressed the Canadian students involved, even though they were technically the majority, at least among the arrestees. ${ }^{100}$ Instead the emphasis was on the foreign danger represented by events like those that took place at Sir George Williams University.

The discussion of the Sir George Williams affair is evidence of a change in the discussion of international students. From 1945 to 1969, the general opinion among parliamentarians had been that foreign students were going to benefit from Canada - that Canadians would shape their views and behaviour, and in doing so would advance Canada's interests in the Cold War. But the Sir George Williams affair demonstrated, in the eyes of many MPs, that international students were a threat to Canada - that they represented a fundamental challenge to the structure 
and well-being of Canadian society. The activists at Sir George Williams had rebelled against the racism of Canadian society, and parliamentarians' response was to reevaluate international students as a group. Coming as it did in a time of general concern about the dangers represented by new arrivals to Canada, the shadow of the Sir George Williams affair would loom in the minds of MPs well into the next decade, and would help precipitate a shift towards mistrust and exclusion in policy talk about international students. ${ }^{101}$

\section{9-1975: International Students as Dangerous Immigrants}

After the Sir George Williams University occupation, the next six years of policy talk regarding international students was defined by discourses of risk and danger. Sometimes this was framed as political danger, more often as economic competition, and occasionally as a threat to academic standards. Regardless, the tone had shifted, and the self-satisfied neo-imperialism of the 1950s and 1960s had given way to a much more fraught discussion of the future of Canada, as imagined through international students.

The notion of international students as political threat was consistently framed as an issue related to student activism and the dangers of Marxism or various versions of communism. In 1974, Conservative MP Duncan Beattie railed about foreign students that "are allowed to enter our country without proper screening and without follow up supervision. People who would not otherwise qualify for landed immigrant status are flooding into the country under cover of our lax foreign student programs." ${ }^{102}$ For Beattie, the real danger was political radicals. He linked the lax student entry requirements to another program he was concerned about, the refugee system for Chileans fleeing the Pinochet coup. Beattie was clear about his concern - as with international students, it was the lack of screening for political radicals. "Is there some magic formula for deciding who is a bona fide refugee," he asked, "or is it only necessary for a person to sidle up to a Canadian immigration officer and say: 'I am a Marxist terrorist and the present government in Chile won't let me engage in subversive activities?" "103 In the early 1970 s, international students were a political threat, potential vehicles for radical (and foreign) political philosophies.

Beyond the political risks represented by international students, there were also the economic risks - that is, the danger that they might take the place of Canadians, either in school or in the job market. In the months after the Sir George Williams University affair, a new tension surfaced within policy talk regarding international students - their place in the farm economy. In May 1969, the minister of Manpower and Immigration, Allan MacEachen, promised Parliament that, for the summer of 1969 , his department was reducing the number of international students from developing countries who were being brought to Canada on exchange, so that there would be more jobs available to Canadian students looking for work. ${ }^{104}$ In July, he reviewed the effects of his policies, telling Parliament that he felt they had been mostly effective and mentioning that reducing the number of jobs for foreign students was part of why they had been effective. ${ }^{105}$ 
The discursive tension regarding international students and work persisted in policy talk throughout the next decade. There was often great concern about the danger of international students taking jobs that could go to Canadian students. ${ }^{106}$ These debates seem to have had an effect on policy, since the Liberal government introduced a work visa system that restricted jobs for international students. ${ }^{107}$ Robert Andras, the minister of Manpower and Immigration who was behind the policy, made it clear that it would only deny work to a specific category of international students, those who had come on their own, by which he meant were economically selfsustaining. For those students who had been promised economic support by Canada, work would still be allowed. He also promised that any international student could apply for "jobs that cannot be filled by Canadians." 108

Soon after the farm work debate, international students were once again the subject of policy talk that evinced an uneasiness with the economic changes Canada was undergoing. While parliamentarians had previously hoped to impart useful skills to international students, after 1970 there was a growing concern about international students taking places in Canadian professional schools. This concern demonstrates the complex discourses in action: on the one hand, international students were a threat because they were staying in Canada after graduating. On the other, professional skills taught to international students were wasted. Regardless of international students' actual plans, they were discursively excluded from consideration as Canadians - they were outsiders, and investments in their education represented money, space, and time that was not a benefit to the Canadian populace.

This debate coalesced around a concern about medical school. In light of the advent of Medicare, according to Conservative MP Jake Epp, there was a pressing demand for spaces for medical students. Yet "a high proportion of foreign students" were enrolled in Canadian medical schools - taking seats that could potentially go to Canadians. ${ }^{109}$ While the federal government tried to insist this was a provincial question, ${ }^{110}$ the Tories continued to press the government, demanding that it account for the exact number of foreign students in Canadian medical schools, as well as their immigration status and the cost to the government of educating them. ${ }^{11}$ Eventually they got their numbers, and Conservative MP Philip Rynard announced them in Parliament-26 per cent of the University of Toronto's medical class that year had been non-Canadian, and each student was costing the government $\$ 75,000 .{ }^{112}$ Despite numbers that were meant to shock, the government's response was to again aver that this was a provincial responsibility. Regardless of the response, the point was made, and the line drawn: international students, Rynard and others could insist, were surely taking Canadian spots and on the taxpayer's dime. More importantly, Canada could clearly not benefit enough from this arrangement to justify support for it. There was no indication of the notion of the goodwill this might create, as would have been present a few years earlier. Nor was there any sense that these students might be future Canadians. Policy talk about international students clearly demonstrated that the discourses underpinning those discussions had shifted since the 1960s.

Although there continued to be some concern about the political activism of international students even into the $1980 \mathrm{~s},{ }^{113}$ and considerably more concern about 
Canadians losing out on seats in classrooms, ${ }^{114}$ the bulk of the parliamentary discussion about international students between 1970 and 1975 revolved around their place in Canada's economy - as workers, or as recipients of government support. Compared to the paternalist charity that was so central to discussions of international students before 1970, these policy discussions were shaped by a discourse that showed a growing concern that international students were not only taking seats away from Canadian students, but also jobs. Moreover, they featured the clearest statements made to that point of the idea that financial support for international students was a cost that could not be borne by Canadian universities or the government.

The work visa policy the government introduced in 1969 explicitly labeled an emerging split in the discussion of international students - the division between recipients of charity, who by 1973 were seen as a danger to Canadian students, and the more appealing students, who were economically self-sustaining. It is a familiar discourse to a contemporary audience, but it had surprisingly little take-up at first in the 1970s. For example, in a long debate in 1972 about amendments to the transfer of funds to provinces for education, there was substantial concern expressed by members of both government and opposition parties about how much of the transfer money paid for international students to attend school. ${ }^{115}$ A wide variety of opinions were expressed, including some uneasiness with increasing international student fees $^{116}$ and even the expression of the old ideal of international students as worthy beneficiaries of charity. ${ }^{117}$ Eventually the discussion focused on the simple reality that funding was needed for schools, and that costs were climbing rapidly. Robert McCleave, a senior Conservative caucus member, summed up this tension with a quote from the Association of Universities and Colleges of Canada: "If adequate financial support is not forthcoming the universities, having made what economies are appropriate and possible, have two options: turn away students who wish to attend or allow quality to deteriorate." 118

With this bleak pronouncement hanging over the debate, international students were primarily positioned as costs that the system could not bear. When differential fees arose as a possible solution, Tory Marcel Lambert announced that he had "never heard anything so chauvinistic as this idea." 119 He still complained about the size of the grant the federal government was giving to provinces to manage higher education, but he did not follow through with the idea that some of the cost could be borne by international students. In fact, it was not until 1987 that a parliamentarian would openly embrace the higher fees paid by international students as a solution to declining government transfers. ${ }^{120}$ While today policy-makers look towards international students to make up budget shortfalls, in the 1970s the discussion focused on them as an economic threat.

There were more discursive shifts on their way, and even as parliamentarians fretted about the risks of "Mao followers" coming to Canada and filling low-wage temporary jobs on farms, the conditions to force a seismic change in discourse and policy talk were already present. As Bryan Palmer has said about the period before 1970, "the Canadian state basked in the seeming calm of what has come to be regarded as the highwater mark of a Fordist regime of accumulation." But, "the glue" for the 
post-war compromise between labour and capital that had made Canada's welfare state possible was "primarily economic, and it started to exhibit stresses in the 1960s. By 1975, the glue was gone and the settlement was falling apart." ${ }^{21}$

What was happening was a shift in international capitalist economies: "faced with stagnant or shrinking markets, rising resource prices, increased foreign competition, and a labour movement ready to defend its living standards, capital experienced reduced profit margins on existing investments and few profitable new opportunities." 122 The result was that capital demanded concessions from the state, which in Canada "involved new subsidies to capital in the form of loans, grants, and tax concessions, thus underwriting investment and shifting the cost of the welfare state onto employed workers." For governments, this meant "deficits ballooned as expenditures rose on corporate subsidies, the unemployed, and public sector wages." 123 So dawned what historian Paul Axelrod calls the "more scholar for the dollar" era in higher education. ${ }^{124}$ Facing these sorts of pressures, parliamentarians began to rethink their attitudes towards international students. None of the existing discourses would be sufficient - international students could not be regarded as targets for aid, as every dollar now had to be accounted for and demonstrate its purpose. On the other hand, emerging global trade relationships and a diversifying population meant that nativist exclusion also no longer served anything but crass domestic politicking.

Table 1

International Student Enrolment Rates in Universities

\begin{tabular}{|c|c|c|c|}
\hline & $\begin{array}{c}\text { International } \\
\text { Students }\end{array}$ & All Students & Percentage \\
\hline $1958-59$ & 5,988 & 94,400 & 6.3 \\
\hline $1961-62$ & 7,900 & 128,864 & 6.1 \\
\hline $1973-74$ & 14,246 & 479,686 & 3.0 \\
\hline $1976-77$ & 28,744 & 543,489 & 5.3 \\
\hline
\end{tabular}

Sources: Dominion Bureau of Statistics, Education division. University Student Expenditure and Income in Canada, 1961-62: Part 1-Non-Canadian Students Catalogue number 81-519, Ottawa, ON, 1963; Max von Zur-Muehlen, The Foreign Student Issues in 1976-77 (Ottawa, ON: Canadian Bureau for International Education, 1977), 30-31.

Thus new discourses were necessary. While some would try to insist on the importance of past ideas about international students - Gordon Fairweather believed "very firmly that this sort of 'scholars for dollars,' surely one of the most demeaning slogans of the past two or three years, could have serious implications for Canada" ${ }^{125}$ — the end of the post-war settlement meant new priorities for the Canadian state. Just as they were in the 1960s and 1970s, international students continued to be objects upon which parliamentarians could project their intentions in this new era. This is one final important legacy of this period: international students were infrequently discussed in the 1940s and 1950s. But by 1970 they had become an important and 
oft-discussed topic in Parliament, a trend that continues today. Likely this reflects their growing numbers and the increasing attention paid to higher education as a whole. Absolute numbers of international students in Canada had climbed alongside overall enrolment in university, although not at the same pace - a smaller proportion of university populations were non-Canadian in the mid-1970s than had been the case in the late 1950 s (see table 1 on the previous page).

\section{Conclusion}

Policy talk about international students has always been shaped and defined by the context within which it has taken place. In the years after the Second World War, Canadian politicians looked at international students through a Cold War lens, and as targets for Canada's largesse. In this neo-colonial view, international students were sojourners, short-term visitors to Canada who would return to their home countries with the lessons learned in Canadian universities and having adopted the values of Canadian liberal capitalism. But by the time the anti-racist protests of students at Sir George Williams University occurred in 1969, policy talk about international students had shifted, reflecting a fear that international students might settle in Canada and a discourse that suggested they were dangerous outsiders threatening the structure of Canadian society. These discourses were part of a broader discussion of Canada's changing immigration regime, but they meant substantial changes in the way international students were discussed in Canada. For modern policy analysts, this historical view is important - a reminder that education policy is never generated in a vacuum. Instead, it is talked about and ultimately created by policymakers who are deeply enmeshed in the larger questions of their time. As such, it behooves us to carefully reconstruct the context within which policy is talked about and ultimately constructed, in order to understand the underlying assumptions that contribute to its shape.

\section{Notes}

The author would like to thank Lisa Brunner, Zhaoying Hu, Katie Gemmell, and the rest of EDST 504A for their help with this paper. Special thanks to Jason Ellis, Mark Leier, and Noël Patten. The author is also grateful to the anonymous reviewers for their comments, which have improved the final product.

1 House of Commons, Debates, 13 December 1976 (R. G. L. Fairweather, Progressive Conservative), http://parl.canadiana.ca/view/oop.debates_HOC3002_02/886? r=0\&s=3.

2 Ontario had doubled fees for international students a few months earlier. See Paul Axelrod, Scholars and Dollars: Politics, Economics, and the Universities of Ontario 19451980 (Toronto: University of Toronto Press, 1982), 200.

3 Marjorie Johnstone and Eunjung Lee, "Branded: International Education and 21st Century Canadian Immigration, Education Policy, and the Welfare State," International Social Work 57, no. 3 (2014): 209-221, doi: 10.1177/0020872813508572. 
4 Leo Panitch, "The Role and Nature of the Canadian State," in The Canadian State: Political Economy and Political Power, ed. Leo Panitch (Toronto: University of Toronto Press, 1977), 3-27.

5 David Tyack and Larry Cuban, Tinkering Toward Utopia: A Century of Public School Reform (Cambridge, MA: Harvard University Press, 1995), 85.

6 Ibid.

7 Ibid., 40.

8 Stephen J. Ball, Education Policy and Social Class: The Selected Works of Stephen J. Ball (London: Routledge, 2006), especially 43-53.

9 Tyack and Cuban, Tinkering Toward Utopia, 40.

10 For more on these parameters, see Rianne Mahon, "Canadian Public Policy: The Unequal Structure of Representation," in The Canadian State: Political Economy and Political Power, ed. Leo Panitch (Toronto: University of Toronto Press, 1977), 165-198.

11 Tyack and Cuban, Tinkering Toward Utopia, 5, 10.

12 This view is heavily shaped by Ball, Education Policy and Social Class.

13 I will argue here that a considerable portion of this policy is created without serious attention to international students themselves, thus the students are really objects of that policy. Of course, as Ball reminds us, "we cannot predict or assume, much to the chagrin of politicians, how [policies] will be acted on in every case in every setting, or what their immediate effect will be, or what room for manoeuvre actors will find for themselves" (Education Policy and Social Class, 46). This article does not address policy directly but is instead predominantly exploring policy talk. Thus, even taking Ball's point, international students largely figure here as absent objects, rather than subjects.

14 A note about terminology: there are two terms used most frequently in parliamentary discussion to describe people studying in Canada whose citizenship is not Canadian — "foreign students" and "international students." In a contemporary setting, these are not interchangeable terms - as Michelle Suderman states, "foreign students overemphasizes strangeness" (2). But historically this is not as clearly true - instead, foreign students was the dominant term until the 1980s. This article will use them both, and will attempt to avoid anachronism by not reading contemporary emphasis into older sources. See Michelle Suderman, "Engagement for All?: A Study of International Undergraduates at the University of British Columbia” (Ed.D. thesis, University of British Columbia, 2015), 2.

15 David R. Morrison, Aid and Ebb Tide: A History of CIDA and Canadian Development Assistance (Waterloo: Wilfrid Laurier University Press, 1998), 5.

16 Robert Bothwell, Alliance and Illusion: Canada and the World, 1945-1984 (Vancouver: UBC Press, 2007).

17 "Moral superpower" is Norman Hillmer's phrase, as quoted in Bothwell, Alliance and Illusion, 8.

18 Bothwell, Alliance and Illusion, 8; and Arthur Andrew, The Rise and Fall of a Middle Power: Canadian Diplomacy from King to Mulroney (Toronto: James Lorimer, 1993).

19 Bothwell, Alliance and Illusion.

20 Andrew, The Rise and Fall of a Middle Power, 25.

21 John W. Holmes, The Better Part of Valour: Essays on Canadian Diplomacy (Toronto: McClelland and Stewart, 1970), 5.

22 Morrison, Aid and Ebb Tide, 27.

23 Ibid., 21-22, 27.

24 Keith Spicer, "The Administration of Canadian Colombo Plan Aid," International Journal 16, no. 2 (1961): 169-182, http://doi.org/10.2307/40198482.

25 Robert Carty, Virginia Smith, and the Latin America Working Group, Perpetuating Poverty: The Political Economy of Canadian Foreign Aid (Toronto: Between the Lines, 1981), 39. 
26 Not a lot has been written about international education as part of aid programs at mid-century. See Roopa Desai Trilokekar, "International Education as Soft Power?: The Contributions and Challenges of Canadian Foreign Policy to the Internationalization of Higher Education," Higher Education 59, no. 2 (2010): 131-147, http://doi. org/10.1007/s10734-009-9240-y, and John D. Allison, "Federalism, Diplomacy and Education: Canada's Role in Education-Related International Activities, 1960-1984," (Ph.D. thesis, University of Toronto, 1999).

27 Trilokekar, "International Education as Soft Power?".

28 Ibid., 133.

29 Costas Melakopides, Pragmatic Idealism: Canadian Foreign Policy, 1945-95, (Montreal: McGill-Queen's University Press, 1998), 3.

30 Spicer, "The Administration of Canadian Colombo Plan Aid," 170.

31 Carty, Smith, and Latin America Working Group, Perpetuating Poverty, 39.

32 Spicer, "The Administration of Canadian Colombo Plan Aid."

33 Carty, Smith, and Latin America Working Group, Perpetuating Poverty, 40.

34 Stephen Brown, "Canada's Foreign Aid Before and After CIDA: Not a Samaritan State," International Journal 68, no. 3 (2013): 501-512, http://doi. org/10.1177/0020702013505730. The quotation is from p. 504.

35 John Willinsky, Learning to Divide the World: Education at Empire's End, (Minneapolis: University of Minneapolis Press, 1997). See also A. J. Angulo, Empire and Education: A History of Greed and Goodwill from the War of 1898 to the War on Terror (New York: Palgrave Macmillan, 2012).

36 This attitude is less surprising when one considers that the residential school system was in full effect in this period. Though politicians never made this link in parliament, the attitudes they show towards international students echo some of the colonial discourses that shaped the residential school system as well. See J.R. Miller, Shingwauk's Vison: A History of Native Residential Schools (Toronto: University of Toronto Press, 1996); John S. Milloy, A National Crime: The Canadian Government and the Residential School System, 1879-1986 (Winnipeg: University of Manitoba Press, 1999).

37 Vijay Prashad, The Darker Nations: A People's History of the Third World (New York: The New Press, 2008).

38 Kwame Nkrumah, Neo-colonialism: The Last Stage of Imperialism (London: Nelson, 1965), 239.

39 Ania Loomba, Colonialism/Postcolonialism (London: Routledge, 2008), 6.

40 Kuan-Hsing Chen, Asia as Method: Towards Deimperialization (Durham, NC: Duke University Press, 2010), 110.

41 For example, see House of Commons, Debates, 31 July 1963 (J. C. Munro, Liberal), http://parl.canadiana.ca/view/oop.debates_HOC2601_03/824?r=0\&s=1; House of Commons, Debates, 13 February 1967 (P. Martin, Liberal), http://parl.canadiana. ca/view/oop.debates_HOC2701_12/719?r=0\&s=1; House of Commons, Debates, 17 December 1973 (J. H. Faulkner, Liberal), http://parl.canadiana.ca/view/oop. debates_HOC2901_08/682?r=0\&s=1.

42 House of Commons, Debates, 6 May 1953 (S. Knowles, Cooperative Commonwealth Federation), http://parl.canadiana.ca/view/oop.debates_HOC2107_05/474?r=0\&s=1.

43 House of Commons, Debates, 6 May 1953 (S. Knowles, Cooperative Commonwealth Federation), http://parl.canadiana.ca/view/oop.debates_HOC2107_05/474?r=0\&s=1 .

44 House of Commons, Debates, 16 February 1961 (W. Pitman, New Democratic Party), http://parl.canadiana.ca/view/oop.debates_HOC2404_02/1060? r=0\&s=1.

45 House of Commons, Debates, 11 September 1961 (F. McGee, Progressive Conservatives), http://parl.canadiana.ca/view/oop. debates_HOC2404_08/143?r=0\&s=1. 
46 House of Commons, Debates, 11 September 1961 (F. McGee, Progressive Conservatives), http://parl.canadiana.ca/view/oop. debates_HOC2404_08/143? r=0\&s=1.

47 House of Commons, Debates, 11 September 1961 (F. McGee, Progressive Conservatives), http://parl.canadiana.ca/view/oop. debates_HOC2404_08/143? r=0\&s=1.

48 For a discussion of the politicized meaning of "Third World," see Prashad, The Darker Nations.

49 Dominion Bureau of Statistics, University Student Expenditure and Income in Canada, 1961-62, Part 1: Non-Canadian Students, 15-17.

50 House of Commons, Debates, 28 November 1963 (R. N. Thompson, Social Credit), http://parl.canadiana.ca/view/oop.debates_HOC2601_05/1155?r=0\&s=1.

51 House of Commons, Debates, 28 November 1963 (R. N. Thompson, Social Credit), http://parl.canadiana.ca/view/oop.debates_HOC2601_05/1155?r=0\&s=1.

52 House of Commons, Debates, 20 September 1983 (S. Hudecki, Liberal), http://parl. canadiana.ca/view/oop.debates_HOC3201_24/322? r=0\&s=1.

53 House of Commons, Debates, 24 February 1964 (A. Webster, New Democratic Party), http://parl.canadiana.ca/view/oop.debates_HOC2602_01/164? $\mathrm{r}=0 \& \mathrm{~s}=1$.

54 House of Commons, Debates, 12 April 1965 (R. Scott, New Democratic Party), http:// parl.canadiana.ca/view/oop.debates_HOC2603_01/260? $\mathrm{r}=0 \& s=1$.

55 House of Commons, Debates, 26 May 1969 (M. Sharp, Liberal), http://parl.canadiana. ca/view/oop.debates_HOC2801_08/1003? $\mathrm{r}=0 \& s=1$.

56 This is not to say that all international education efforts were inherently colonial. Indeed, Ruth Compton Brouwer has shown that some, in this case Canadian University Service Overseas (CUSO), were anti-colonial. See Ruth Compton Brouwer, Canada's Global Villagers: CUSO in Development, 1961-86 (Vancouver: UBC Press, 2013).

57 As quoted in Carty, Smith, and Latin America Working Group, Perpetuating Poverty, 41.

58 House of Commons, Debates, 13 February 1967 (R. Langlois, Ralliement créditiste), http://parl.canadiana.ca/view/oop.debates_HOC2701_12/719? $\mathrm{r}=0 \& s=1$.

59 The actual amount is unclear. Secretary of State for Foreign Affairs Paul Martin had told the house the day before that there were 1,475 international students in Canada in 1967, and that "the average cost to the Canadian government for students brought to Canada since the inception of the program is \$5,467.29 per annum." See House of Commons, Debates, 13 February 1967 (P. Martin, Liberal), http://parl.canadiana.ca/ view/oop.debates_HOC2701_12/719? $\mathrm{r}=0 \& s=1)$. It is hard to tell from this statement whether Martin meant the average annual cost in total or the cost per student. It is a generous grant on a per student level (more than a labourer or a clerk would have made in a year in Toronto in 1965, according to Statistics Canada, Average Wage and Salary Rates for Selected Occupations in Certain Cities across Canada, October 1, 1965, http:// www65.statcan.gc.ca/acyb02/1967/acyb02_19670763024a-eng.htm (last accessed 5 August 2015), but seems an impossibly small amount for the program as a whole. Considering that the number of international students that Martin references is far lower than the actual total, one must assume that he means only the students who were receiving government funding - that is, aid.

60 House of Commons, Debates, 14 February 1967 (R. Langlois, Ralliement créditiste), http://parl.canadiana.ca/view/oop.debates_HOC2701_12/845? r=0\&s=1.

61 House of Commons, Debates, 14 February 1967 (R. Langlois, Ralliement créditiste), http://parl.canadiana.ca/view/oop.debates_HOC2701_12/845? r=0\&s=1.

62 House of Commons, Debates, 16 February 1967 (R. Langlois, Ralliement créditiste), http://parl.canadiana.ca/view/oop.debates_HOC2701_12/899? r=0\&s=1. 
63 House of Commons, Debates, 14 February 1967 (R. Langlois, Ralliement créditiste), http://parl.canadiana.ca/view/oop.debates_HOC2701_12/845?r=0\&s=1.

64 House of Commons, Debates, 14 February 1967 (R. Langlois, Ralliement créditiste), http://parl.canadiana.ca/view/oop.debates_HOC2701_12/845?r=0\&s=1.

65 House of Commons, Debates, 16 February 1967 (R. Langlois, Ralliement créditiste), http://parl.canadiana.ca/view/oop.debates_HOC2701_12/899?r=0\&s=1.

66 Robert Harney, "'So Great a Heritage as Ours': Immigration and the Survival of the Canadian Polity," Daedalus 117, no. 4 (1988): 51-97. The quotation is from p. 60.

67 Harney, "So Great a Heritage," " 54.

68 Reg Whitaker, Canadian Immigration Policy Since Confederation (Saint John, NB: Canadian Historical Association, 1991).

69 Whitaker, Canadian Immigration Policy, 19.

70 Harney, "'So Great a Heritage,'” 59.

71 Whitaker, Canadian Immigration Policy, 19.

72 Franca Iacovetta, Gatekeepers: Reshaping Immigrant Lives in Cold War Canada (Toronto: Between the Lines, 2006), 10-11.

73 Iacovetta, Gatekeepers, 18.

74 Harney, "'So Great a Heritage,' ” 91-2.

75 Ibid.

76 Ibid., 52.

77 José E. Igartua, The Other Quiet Revolution: National Identities in English Canada, 1945-71 (Vancouver: UBC Press, 2006), 12-13.

78 For more on the political conflict surrounding the creation of multiculturalism, see Kenneth McRoberts, Misconceiving Canada: The Struggle for National Unity (Toronto: Oxford University Press, 1997) and Patricia E. Roy, "The Fifth Force: Multiculturalism and the English Canadian Identity," Annals of the American Academy of Political and Social Science 538 (March 1995): 199-209. For an argument suggesting that multiculturalism is inherently neo-colonial, see Chen, Asia as Method, 97-99. For more on the history of multiculturalism as exclusive in Canada, see Himani Bannerji, "Geography Lessons: On Being an Insider/Outsider to the Canadian Nation," in The Dark Side of the Nation: Essays on Multiculturalism, Nationalism and Gender (Toronto: Canadian Scholars' Press, 2000), 63-86.

79 Benedict Anderson, Imagined Communities: Reflections on the Origins and Spread of Nationalism (London: Verso, 1991), 7.

80 For more on the student revolt on English-Canadian campuses, see Roberta Lexier, “ 'The Backdrop Against Which Everything Happened': English-Canadian Student Movements and Off-Campus Movements for Change," History of Intellectual Culture 7, no. 1 (2007): 169-190; "Dreaming of a Better World: Student Rebellion in 1960s Regina,” Past Imperfect 10 (2008): 79-98; “To Struggle Together or Fracture Apart: The Sixties Student Movements at English-Canadian Universities," in Debating Dissent: Canada and the Sixties, ed. Lara Campbell, Dominique Clément, and Gregory S. Kealey (Toronto: University of Toronto Press, 2012), 80-96.

81 See David Austin, "All Roads Led to Montreal: Black Power, the Caribbean, and the Black Radical Tradition in Canada," Journal of African American History 92, no. 4 (2007): 516-539; Bryan D. Palmer, Canada's 1960s: The Ironies of Identity in a Rebellious Era (Toronto: University of Toronto Press, 2009), 284-7; Sean Mills, The Empire Within: Postcolonial Thought and Political Activism in Sixties Montreal, (Montreal: McGill-Queen's University Press, 2010), 95-118; Marcel Martel, “'Riot' at Sir George Williams: Giving Meaning to Student Dissent," in Debating Dissent: Canada and the Sixties, ed. Lara Campbell, Dominique Clément, and Gregory S. Kealey (Toronto: University of Toronto Press, 2012), 97-114. 
82 House of Commons, Debates, 30 January 1969 (W. B. Nesbitt, Progressive Conservatives), http://parl.canadiana.ca/view/oop.debates_HOC2801_05/394?r=0\&s=3.

83 Martel, "'Riot' at Sir George Williams," 104.

84 Bannerji, "Geography Lessons," 64-5.

85 Mills, The Empire Within, 96.

86 Mills, The Empire Within.

87 Austin, "All Roads Led to Montreal," 533.

88 Mills, The Empire Within, 109.

89 Ibid., 104-5.

90 House of Commons, Debates, 30 January 1969 (W. B. Nesbitt, Progressive Conservative), http://parl.canadiana.ca/view/oop.debates_HOC2801_05/394?r=0\&s=3; House of Commons, Debates, 12 February 1969 (T. Ricard, Progressive Conservative), http://parl.canadiana.ca/view/oop.debates_HOC2801_05/394? r=0\&s=3; House of Commons, Debates, 12 February 1969 (R. Muir, Progressive Conservative), http://parl. canadiana.ca/view/oop.debates_HOC2801_05/884? r=0\&s=3; House of Commons, Debates, 12 February 1969 (P. Yewchuk, Progressive Conservative), http://parl. canadiana.ca/view/oop.debates_HOC2801_05/394? r=0\&s=3; House of Commons, Debates, 13 February 1969 (E. M. Woolliams, Progressive Conservative), http://parl. canadiana.ca/view/oop.debates_HOC2801_05/919?r=0\&s=3; House of Commons, Debates, 12 February 1969 (R. Muir, Progressive Conservative), http://parl.canadiana. ca/view/oop.debates_HOC2801_05/921? r=0\&s=3.

91 House of Commons, Debates, 13 February 1969 (W. Allmand, Liberal), http://parl. canadiana.ca/view/oop.debates_HOC2801_05/919? r=0\&s=3.

92 House of Commons, Debates, 13 February 1969 (G. Rondeau, Ralliement créditiste), http://parl.canadiana.ca/view/oop.debates_HOC2801_05/919? r=0\&s=3.

93 House of Commons, Debates, 13 February 1969 (H. Latulippe, Ralliement créditiste), http://parl.canadiana.ca/view/oop.debates_HOC2801_05/919? $\mathrm{r}=0 \& s=3$.

94 House of Commons, Debates, 13 February 1969 (E. M. Woolliams, Progressive Conservative), http://parl.canadiana.ca/view/oop.debates_HOC2801_05/919?r=0\&s=3.

95 House of Commons, Debates, 13 February 1969 (M. Prud'homme, Liberal), http:// parl.canadiana.ca/view/oop.debates_HOC2801_05/919?r=0\&s=3. One Grenadian student, Kennedy Frederick, was eventually deported for his role in the affair. See Palmer, Canada's 1960s, 286.

96 A. D. Hales, as quoted in Martel, " 'Riot' at Sir George Williams," 104.

97 House of Commons, Debates, 12 February 1969 (P. Yewchuk, Progressive Conservatives), http://parl.canadiana.ca/view/oop. debates_HOC2801_05/394? $r=0 \& s=3$.

98 House of Commons, Debates, 22 October 1969 (A. D. Hales, Progressive Conservative), http://parl.canadiana.ca/view/oop.debates_HOC2801_10/1387? r=0\&s=2.

99 House of Commons, Debates, 13 February 1969 (H. Latulippe, Ralliement créditiste), http://parl.canadiana.ca/view/oop.debates_HOC2801_05/884? $r=0 \& s=3$.

100 It is not just Canada's Parliament that emphasized the foreign element in the Sir George Williams affair. Austin describes anger towards Canada throughout the Caribbean in the aftermath of the riot, with the governor general confronted by students in Trinidad, Jamaica, and Barbados while visiting them on a goodwill tour in 1969 (see Austin, "All Roads Led to Montreal," 533). The international profile was likely because of its connection to the Black Power movement in the United States (the students involved had published several of Stokely Carmichael's essays in Canada), but also because of some of the people involved in the protest. Cheddi Jagan, the son of the former (and future) presidents of Guyana (his parents, Cheddi Sr. and Janet, both served as president of Guyana at different times), was among the occupiers, and Rosie Douglas was also 
well known and would go on to become the prime minister of Dominica. At the time, Austin explains, McGill was regarded as a premier educational institution throughout the Caribbean. But its discriminatory admission system meant that, while they were drawn to Montreal by McGill, many Caribbean international students ended up studying in the more accessible Sir George Williams University.

101 For more on the perception of immigrants as dangerous in the Cold War era, see Iacovetta, Gatekeepers.

102 House of Commons, Debates, 11 March 1974 (D. M. Beattie, Progressive Conservative), http://parl.canadiana.ca/view/oop.debates_HOC2902_01/374?r=0\&s=3.

103 House of Commons, Debates, 11 March 1974 (D. M. Beattie, Progressive Conservative), http://parl.canadiana.ca/view/oop.debates_HOC2902_01/374? r=0\&s=3.

104 House of Commons, Debates, 1 May 1969 (A. J. MacEachen, Liberal), http://parl. canadiana.ca/view/oop.debates_HOC2801_08/183? $\mathrm{r}=0$ \& $s=1$.

105 House of Commons, Debates, 22 July 1969 (A. J. MacEachen, Liberal), http://parl. canadiana.ca/view/oop.debates_HOC2801_10/1238? $\mathrm{r}=0 \& \mathrm{~s}=1$.

106 See, for example: House of Commons, Debates, 12 April 1973 (G. Marceau, Liberal), http://parl.canadiana.ca/view/oop.debates_HOC2901_03/915?r=0\&s=1; House of Commons, Debates, 12 April 1973 (R. K. Andras, Liberal), http://parl.canadiana.ca/ view/oop.debates_HOC2901_03/915? r=0\&s=1.

107 House of Commons, Debates, 1 March 1973 (R. K. Andras, Liberal), http://parl. canadiana.ca/view/oop.debates_HOC2901_02/633? r=0\&s=1.

108 House of Commons, Debates, 1 March 1973 (R. K. Andras, Liberal), http://parl. canadiana.ca/view/oop.debates_HOC2901_02/633? r=0\&s=1.

109 House of Commons, Debates, 10 December 1974 (A. J. Epp, Progressive Conservative), http://parl.canadiana.ca/view/oop.debates_HOC3001_02/1012? r=0\&s=3.

110 House of Commons, Debates, 23 January 1975 (R. K. Andras, Liberal), http://parl. canadiana.ca/view/oop.debates_HOC3001_03/395? r=0\&s=1.

111 House of Commons, Debates, 17 March 1975 (P. B. Rynard, Progressive Conservative), http://parl.canadiana.ca/view/oop.debates_HOC3001_04/895?r=0\&s=1.

112 House of Commons, Debates, 20 March 1975 (P. B. Rynard, Progressive Conservative), http://parl.canadiana.ca/view/oop.debates_HOC3001_04/1073? r=0\&s=1.

113 For example, see House of Commons, Debates, 16 December 1980 (D. Neil, Progressive Conservative), http://parl.canadiana.ca/view/oop. debates_HOC3201_05/1100? $\mathrm{r}=0 \& s=3$.

114 For example, see House of Commons, Debates, 25 March 1977 (J. Diefenbaker, Progressive Conservative), http://parl.canadiana.ca/view/oop. debates_HOC3002_04/1066? r=0\&s=1.

115 See House of Commons, Debates, 16 March 1972 (D. G. Blair, Liberal), http:// parl.canadiana.ca/view/oop.debates_HOC2804_01/895?r=0\&s=1; and House of Commons, Debates, 16 March 1972 (M. Lambert, Progressive Conservative), http:// parl.canadiana.ca/view/oop.debates_HOC2804_01/900? $\mathrm{r}=0$ \&s $=1$.

116 House of Commons, Debates, 16 March 1972 (M. Lambert, Progressive Conservative), http://parl.canadiana.ca/view/oop.debates_HOC2804_01/900?r=0\&s=1.

117 House of Commons, Debates, 16 March 1972 (R. McCleave, Progressive Conservative), http://parl.canadiana.ca/view/oop.debates_HOC2804_01/906? r=0\&s=1.

118 House of Commons, Debates, 16 March 1972 (R. McCleave, Progressive Conservative), http://parl.canadiana.ca/view/oop.debates_HOC2804_01/906?r=0\&s=1.

119 House of Commons, Debates, 16 March 1972 (M. Lambert, Progressive Conservative), http://parl.canadiana.ca/view/oop.debates_HOC2804_01/900?r=0\&s=1.

120 House of Commons, Debates, 12 August 1987 (S. Marchi, Progressive Conservative), http://parl.canadiana.ca/view/oop.debates_HOC3302_07/87? r=0\&s=3. 
121 Bryan D. Palmer, "System Failure: The Breakdown of the Post-War Settlement and the Politics of Labour in Our Time," Labour/Le Travail 55 (2005): 334-346. The quotations are from p. 338.

122 Leo Panitch and Donald Swarz, From Consent to Coercion: The Assault on Trade Union Freedoms, 3rd ed. (Toronto: Garamond Press, 2008), 25.

123 Panitch and Swarz, From Consent to Coercion, 25-6.

124 Axelrod, Scholars and Dollars.

125 House of Commons, Debates, 13 December 1976 (R. G. L. Fairweather, Progressive Conservative), http://parl.canadiana.ca/view/oop.debates_HOC3002_02/886? r=0\&s=3. 